Koryahin, V., Mykytyuk, Z., Turchyn, Y., Blavt, O., Prystynskyi, V., \& Stadnyk, V. (2021). Integration of Information Systems in the Control of Heart Rate in the Process of Physical Education. Teoriâ ta Metodika Fizičnogo Vihovannâ, 21(1), 5-11.

https://doi.org/10.17309/tmfv.2021.1.01

ISSN 1993-7989 (print). ISSN 1993-7997 (online)

\title{
INTEGRATION OF INFORMATION SYSTEMS IN THE CONTROL OF HEART RATE IN THE PROCESS OF PHYSICAL EDUCATION
}

\author{
Victor Koryahin ${ }^{1 \mathrm{ABCD}}$, Zinoviy Mykytyuk ${ }^{1 \mathrm{ABCD}}$, Yaryna Turchyn ${ }^{1 \mathrm{ABCD}}$, \\ Oksana Blavt $^{1 \mathrm{ABCD}}$, Volodymyr Prystynskyi ${ }^{\mathrm{ABCD}}$, Volodymyr Stadnyk ${ }^{1 \mathrm{ABCD}}$ \\ ${ }^{1}$ Lviv Polytechnic National University \\ ${ }^{2}$ State Higher Educational Institution "Donbass State Pedagogical University" \\ Authors' Contribution: A - Study design; B - Data collection; C - Statistical analysis; D - Manuscript Preparation; E - Funds Collection
}

Corresponding Author: Oksana Blavt, E-mail: oksanablavt@ukr.net

Accepted for Publication: March 20, 2021

Published: March 25, 2021

DOI: 10.17309/tmfv.2021.1.01

\begin{abstract}
The study objective. Substantiation and implementation of the heart rate monitoring tool, developed on the basis of information systems for the rapid registration of cardiac rhythm during exercise.

Material and Methods. The study was implemented at the theoretical and empirical level. The basis of the study is the use of a set of theoretical methods: scientific analysis and synthesis, comparison, systematization, induction and deduction, generalization. The following methods of empirical research were used: description, empirical comparison, technical modeling, sphygmographic method of registration of pulsograms.

Results. According to the results of the search activity, a device designed to monitor heart rate in real time was presented. To implement the new electronic method and heart rate monitor of the functional state of the cardiovascular system, an optical block that eliminates the subjective determination of control results associated with the probability of errors was created. The use of an optical unit provides a fast dynamic picture of heart rate measurement, since the unit uses an optical sensor. Spectral characteristics of blood, which change under the influence of physical activity, were used for heart rate registration. Positive characteristics that ensure the quality of real-time HR monitoring procedures using the developed device in addition to high technical parameters are: high level of sensitivity, wide dynamic range, harmonized frequency response, linearity of conversion, note also non-invasiveness, security in application, low energy consumption signal, and transformations that do not affect or distort the control results.

Conclusions. The use of information systems in heart rate control ensures the accuracy of the measurement information and the correspondence between the degree of scientific reliability and practical value of the obtained results.
\end{abstract}

Keywords: physical education, monitoring, heart rate, device, sensor, control.

\section{Introduction}

Problem statement. The effectiveness of physical education is correlated with scientifically sound management of the functional potential of the organism. The effectiveness of the latter is provided by the availability of high-quality operational information about the impact of physical activity on the body (Anikieiev, 2015). On the basis of knowledge about the regularities of the functioning of physiological systems, the expediency of influence of the means of physical culture on the body is determined. Thus, exercise control is exercised during the training (Schmidt \& Lee, 2013).

(C) Koryahin, V., Mykytyuk, Z., Turchyn, Y., Blavt, O.,

Prystynskyi,V., Stadnyk, V., 2021.
The criterion for the adequacy of physical activity, the basis of their regulation and planning in the process of physical education is to determine the physiological reactions of the cardiovascular system. Such monitoring of heart rate (HR) is realized, which is an important indicator of the functional activity of the cardiovascular system and the state of the circulatory system as a whole (Zanevskyy \& Zanevska, 2019). This takes into account the increase in heart rate directly during exercise or the nature of recovery of this indicator after their completion. In the pulse signal of the radial artery are reflected and the processes of higher levels of regulation, and many hemodynamic indicators of the cardiovascular system, including intravascular pressure, arterial wall voltage, wave processes in the arterial system, movement of blood masses and more (Dinesh, Sforzo, \& Swensen, 2007). All these pro- 
cesses, to varying degrees, affect the shape of the pulse wave and its rhythmic structure (Fedorov, 2008).

Therefore, current information on the control of HR dynamics during training is necessary in terms of indicating the intensity of the impact of physical activity on the body. Such control involves: control, assessment of the state of the organism, accumulation of statistics, their analysis, determination of dynamics and trends (Ozemek, Whaley, Holmes Finch, \& Kaminsky, 2017). First of all, it is of paramount importance for the specialists of physical culture for solving the issues of admission to training sessions (Laurson, Brown, Dennis, \& Cullen, 2008), since the HR is available for rapid control of the heart when determining the body's response to physical activity, in the study of physical performance, emotional stress, etc (Ivashchenko, 2020; Oliver \& Stembridge, 2011).

Given that the results of HR monitoring are the basic basis for planning the mode of exercise and the strategy of further physical education in the practice of physical education, it is very important to choose the right method for measuring HR (Arena, Myers, \& Kaminsky, 2016; Jrgensen, Andersen, Froberg, Maeder, von Huth Smith, \& Aadahl, 2009). Currently, several methods are used to determine the HR in the course of training: manual, mechanical, electrical and optical. The most widely used are palpation, photoplethysmography, sphygmography, rheography, electrocardiography (Thomas, Nelson, \& Silverman, 2015; Reiman \& Manske, 2009; Fainsilberg, 2007). However, the technical difficulties that accompany the use of these methods make it impossible to control the HR directly while performing physical work (Nichols, Davis, McCord, Schmidt, \& Slezak, 2013). In some cases, HR cannot be measured at all (during interval training, etc.).

Therefore, despite the wide range of HR control tools in the current practice of physical education, the problem of objective and reliable real-time monitoring of such control has not been solved to date. Given the importance of having information about the cardiovascular system's response to physical activity, the issue of HR control is very important.

Analysis of recent research and publications. The problem of ensuring the reliability of control in physical education has been studied at different times (Alfrey \& Gard, 2014; Osipov et al., 2020; Koryahin, Blavt, \& Ponomaryov, 2019). Nowadays, the possibilities of introduction of innovations in the control of physical education are being given increased attention in the works of specialists of the industry. Trends in the use of new controls in physical education to improve its effectiveness are discussed in the works (Gasser \& Hoppeler, 2015; Vasconcelos, Damorim, Santos, Lima, Santos, Lima, \& Damasceno, 2020).

Many authors have addressed the problem of development of information systems of HR monitoring and diagnostics of the cardiovascular system (Cooper, Watras, O'Brien, Luke, Dobratz, Earthman, \& Schoeller, 2009; Faulkner, Greey, \& Hunsicker, 2013; Yankovenko, 2010). In the scientific researches the methods of electrocardiography and types of pulsometry (sphygmography, plethysmography), which are the most common methods of diagnostics of the condition of the cardiovascular system, and through it - and other organs and systems of the organism, are considered (Dinesh, Sforzo, \& Swensen, 2007; Fainsilberg, 2007; Warburton, Nicol, \& Bredin, 2006). It is determined that the disadvantage of modern HR systems is the complexity and the high cost, the sensors in such systems are purely analog, which causes a decrease in the accuracy of recording the primary signal.
The range of devices with optical HR measurement technology is quite common in publications (Fedorov, 2018; Hotra, Mahlovanyy, Mykytyuk, Ivakh, \& Politanskyi, 2019). It is on the basis of optical sensors that smartphones, bracelets-trackers, watches have been developed, and all the major companies are expanding the line of HR monitors with models with optical sensors (Vasconcelos, Damorim, Santos, Lima, Santos, Lima, \& Damasceno, 2020). However, the development of information systems today allows to implement the processing of the pulse signal by many available methods using a wide range of technical means. Methods for digital processing of pulsations are aimed at computer filtering and selection of useful signal (slate approximation, fourier analysis, various types of wavelet transform) and to determine changes of diagnostic parameters (American College of Sports Medicine, 2013). At the heart of these methods - HR control is carried out according to the normative $\mathrm{HR}$, that is, compare the parameters of the received HR with the diagnostic HR characteristics that were established earlier. According to contour analysis, pulse curves reflect only the general form of blood pressure fluctuations, and do not provide qualitative and quantitative characteristics of the cardiovascular system. Such techniques are quite complicated both in understanding and in calculations, since they require the early processing of pulse signals from vessels, complex decomposition into spectra, speed of mathematical calculations and programs. The high reliability of the methods in this case is achieved by an individual approach to each individual spectrum, which makes it impossible to automate such a procedure.

We note the recent progress in the use of electronic methods in measuring devices, systems and devices. Moreover, the mutual impact of electronics and measurement tools today and the prospects for this impact on future advances in physical education are evident. It is convincing to look (Fedorov, 2008; Reiman \& Manske, 2009; Sartor, Bonato, Papini, Bosio, Mohammed, \& Bonomi, et al., 2016) at the need to find ways to modernize and identify the means of HR control. According (Yankovenko, 2010; Oliver, \& Stembridge, 2011), it is important to choose the right measurement method, to create sensors with the appropriate specifications, to perform the full range of information processing measures.

Purpose of the research is substantiation and implementation of the HR monitoring tool, developed on the basis of information systems for the rapid registration of cardiac rhythm during exercise.

\section{Materials and methods}

\section{Organization of research}

The study was implemented at the theoretical and empirical level.

The basis of the study is the use of a set of theoretical methods: scientific analysis of synthesis, comparison - as ways of knowing the objective reality, to determine the state of solution of the selected scientific problem, which allowed to study the existing methods of HR monitoring, heart rate currently used in practice and concretization existing methods of analysis of pulsograms; systematization - to justify the feasibility of using computerized HR monitoring systems; induction and deduction for collecting theoretical and factual material for revealing the peculiarities of HR detection tech- 
niques, its generalization for determining the possibilities of using sensors in HR monitoring devices and systems that allow to quantify the functioning of the cardiovascular system.

Among the methods of empirical research were used: description of the proposed method of optical pulsometry and a formal (abstract) description of the signal of movement of the artery wall in view of the availability of information in it; empirical comparison of HR the recording techniques to identify their disadvantages that reduce the practical value of their use; technical modeling was used to create the device to be studied: the use of technical means gave the simulation an experimental character; experimental use of the sphygmographic method of registration of pulsograms and the developed technique of optical pulsometry for the purpose of obtaining empirical data, their visualization in digital and graphical forms for giving objective conclusions.

The experimental study was aimed at eliminating a number of problematic factors and ensuring promptness, objectivity of control procedures, etc. using information systems. This involved the synthesis of new sensors, including nanosensors, with improved technical performance to create a state-of-theart device for efficient HR measurement in real time.

\section{Results}

To realize the purpose of the study, first of all, the assumption was made regarding the shortcomings of sphygmographic HR recording devices, which are now most used in the practice of physical education. There is confidence that they have significant limitations and do not fully meet the needs of control. This is due to low research efficiency and limited signal recording channels. In addition, modern sphygmographic recording systems use sensitive solid-state pressure sensors with an elastic membrane, piezoelectric and pneumatic sensors, the application of which is a significant drawback of the significant influence of vibrations of mechanical origin. There is a likelihood of measurement errors dependent on changes in ambient temperatures. It has been found that the HR determination by a sphygmograph is characterized by low efficiency and limited signal recording channels, which makes it impossible to obtain the pre-existing control results.

To implement the new electronic method and HR monitor of the functional state of the cardiovascular system a created optical block that eliminates the subjective determination of control results associated with the probability of errors.

The use of an optical unit provides a fast dynamic picture of HR measurement, since the unit uses an optical sensor (Malaric, 2011). The feasibility of containing an optical sensor is justified by the simplicity of the structure, the low cost, the acceptable accuracy of operation, the absence of influence on the organism of the subject of monitoring. The optical sensor used is based on an optocoupler that combines a radiation source and an electronic photoconverter. The choice of radiation source parameters is determined by the optical characteristics of the blood, including the absorption coefficient. Spectral characteristics of blood, which change under the influence of physical activity, were used for HR registration. Figure 1 presents the spectral characteristic that reflects the absorption value of venous and arterial blood.

The above dependence has characteristic spectral areas with pronounced peak values of the absorption coefficient.

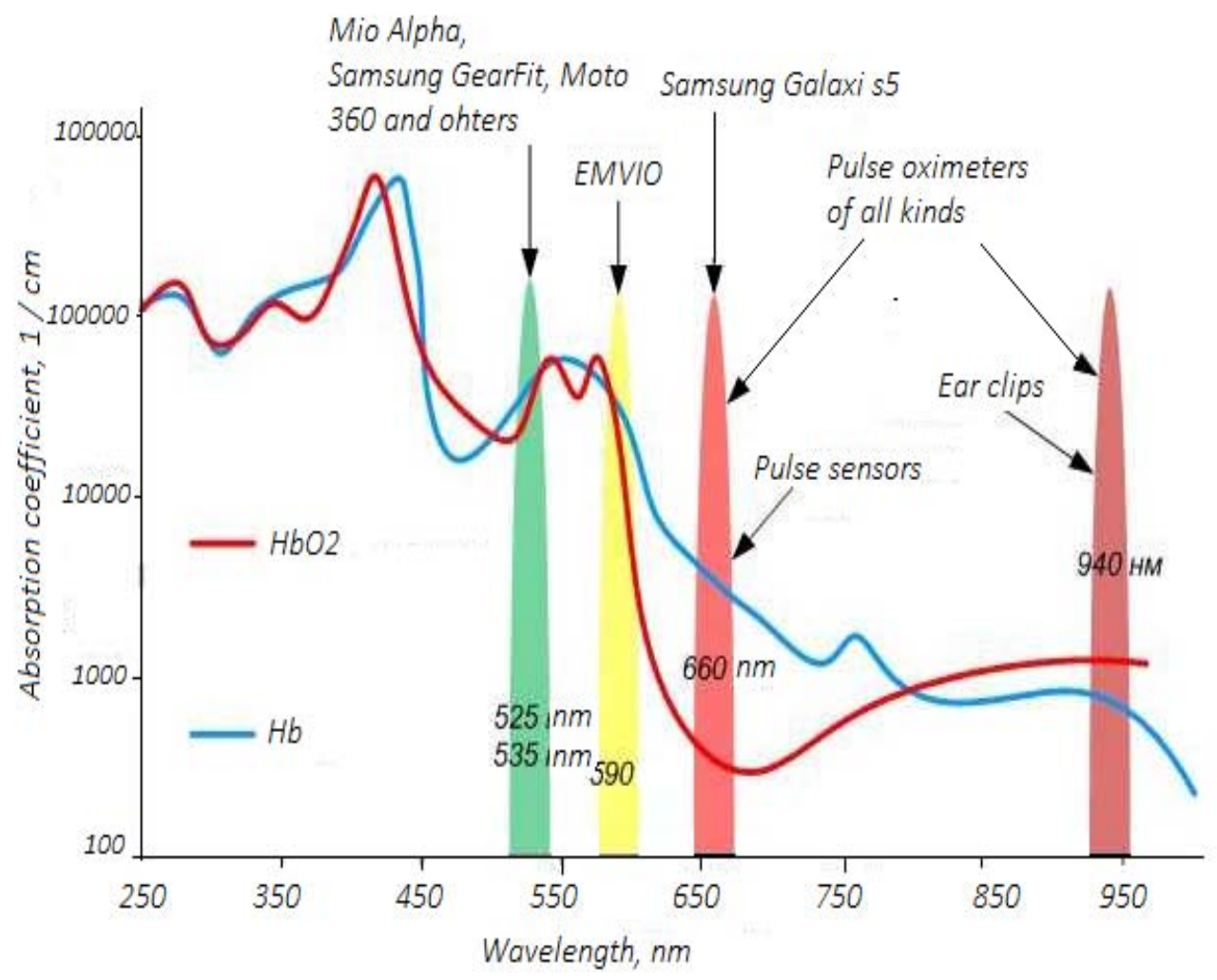

Fig. 1. Spectral characteristics of blood 
These spectral ranges are used to record the HR. The arrows show the spectral ranges used by some manufacturers for the production of HR monitoring devices.

Human skin contains many thin capillaries filled with blood. At a time when the heart is contracting, the blood pressure rises, it enters the blood vessels more actively, which means that it absorbs more light. The sensor records this and determines the HR by calculating the number of such bursts per minute.

The vast majority of optical HR monitors, as can be seen from Fig. 1, use a certain, defined range within which irradiation and registration of the reflected signal are carried out. This approach is easy to implement, however, it has the drawbacks associated with errors that can occur in the absence of good contact between the sensor and the body. The latter is almost impossible to provide during the course.

Another disadvantage of optical HR monitors is the dependence on the body's response to the cold. Any decrease in blood flow (for example, in cold weather) may interfere with the operation of the optical HR sensor. As the body cools, the blood flow in the capillaries decreases, the device becomes much more difficult to capture the contraction of the heart. Therefore, if you belong to the category of people who, in cool weather (even with physical activity), their hands lighten quickly and become cold, the optical heart rate monitor may distort the data obtained during autumn jogging.

Finally, the third drawback of the optical type heart rate monitor is the possible errors at high HR. If under high load the pulse exceeds 150-170 beats - the blood flow velocity becomes too high. Moments of diastolic pressure (lower when the heart relaxes) last a minimum of time and are almost not reflected in capillary blood flow. As a result, the sensor is not able to recognize these moments, resulting in a malfunction of the device (Fedorov, 2008).

To increase the sensitivity of the optical sensor, the optical unit is designed to receive data on the blood spectrum and changes in it under the influence of physical activity, which allows for multi-parameter analysis of the spectral characteristics of blood. The unit uses the VLMU1610-365-135 (Vishay Semiconductors), VLMTG1400 and VSMS3700 LEDs. At a time when the heart is contracting, the blood pressure rises, it enters the blood vessels more actively, which means that it absorbs more light. LEDs record this, and by calculating the number of such bursts per minute, determine the HR.

In order to confirm the effectiveness of the created device, the study of the absorption coefficient of blood in the ultraviolet and infrared spectral range. Since human blood has a red color (that is, it best reflects the optical radiation corresponding to red), for better accuracy it is necessary to use another shade, which is well absorbed by it. This is green, located on the spectral circle opposite to red, which means that it is well absorbed by the blood (Fig. 2).

Based on the obtained results, the HR curves using the spectral analysis realize the qualitative and quantitative characteristics of the state of the cardiovascular system and the HR response to physical activity in real time. The high accuracy of spectral analysis methods is achieved by an individual approach to each individual spectrum of each subject.

Using the developed device, a method of monitoring the functional state of the cardiovascular system, namely HR monitoring, is proposed, at physical activity. The method is to place an optical block with an optical sensor and LEDs

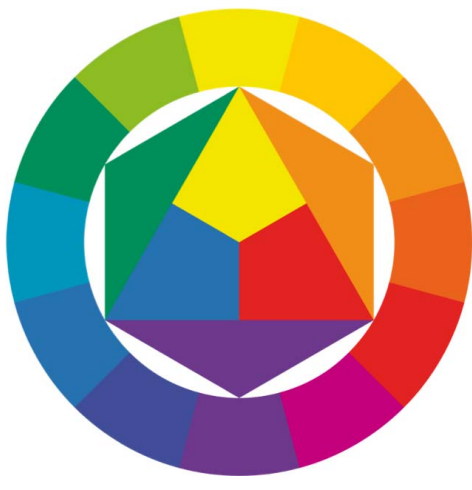

Fig. 2. Color circle by Johannes Iten

on the body of the subject (wrist). The opic sensor with the help of an optocoupler records the intensity of the signals that are formed during movement of the artery wall, which arise under the influence of a wave of blood pressure at each contraction of the heart. Information signals are output to a synchronous detector and fed to the microcontroller. The microcontroller is required to control the optical unit and to measure the signal. Measured by the microcontroller signal, wireless infrared communication devices are provided to the electronic computing device, where the results obtained perform a multi-parameter analysis of the spectral characteristics of the blood, which is judged on changes in HR and functional state of the cardiovascular system in the process of physical training. Displays monitoring results on LCDs using developed software in numerical and graphical form.

To ensure the wireless communication of multiple optical units and to transmit information to the electronic computing device, they use a developed 16-channel multichannel radio modem. Its use provides the recording of the results of HR monitoring of several persons at a time (Fig. 3). Built-in function of viewing both channels and individually. It is possible to specify the magnitude of both the amplitude and time axes.

The operation of the device and the processes of HR registration, accumulation and reading of measurement results are remotely via the Bluetooth interface between the personal computer and the measuring device. For this purpose specially developed software is used. Synchronization of measurement processes is accomplished by real time counter.

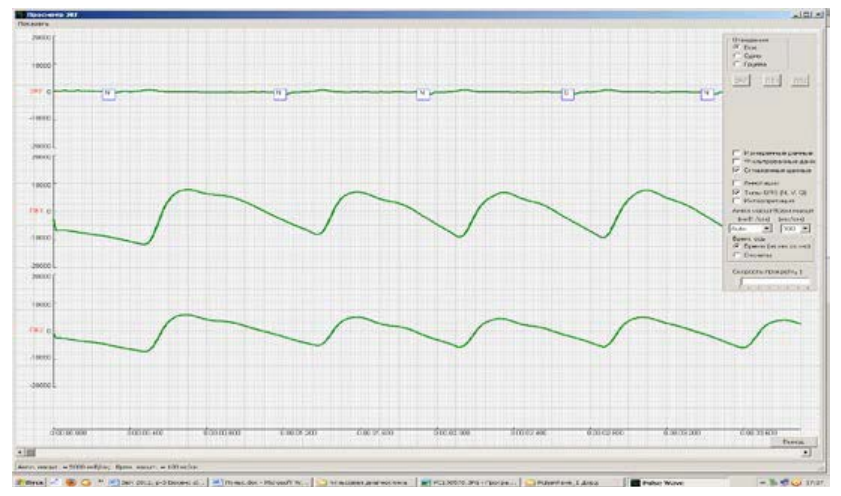

Fig. 3. Example of recording the heart rate of several persons at a time 
The measurement results of the device obtained through the Bluetooth interface are stored as a text file.

It implements the functions of recording, saving with subsequent loading and visualization of the recording. There is a choice of recording duration and a convenient overview of the result. Presentation of control results and continuous observations in the form of electronic protocol, allows to significantly expand and enlarge the range of views, facilitate search and interpretation of the obtained results over a long time, preserve information and conveniently view the dynamics of the results of a particular subject.

Control procedure information requires processing and analysis using quantitative methods that are used to process large data sets. Therefore, we envisage the use of a modern information complex of electronic computers in the structure of the device, which will allow to obtain not only quantitative values of individual parameters, which, when applied to the study of the cardiovascular system, allows to solve a wide range of diagnostic problems.

Summarizing the above, and taking into account the fact that in assessing the possibilities of the proposed method of $\mathrm{HR}$ registration, we consider several considerations, among which the most important are the following:

- high accuracy of the obtained results for the assessment of the condition of the monitoring subject;

- simplicity of implementation of all methodical techniques for preparation of the monitoring subject by this method;

- $\quad$ simplicity and availability of technical means for carrying out research;

- availability of calculation algorithms according to registration data and simplicity of biomedical interpretation of results;

- the possibility of combining this method with others.

Positive characteristics that ensure the quality of realtime HR monitoring procedures using the developed device in addition to high technical parameters - high level of sensitivity, wide dynamic range, harmonized frequency response, linearity of conversion, note also non-invasiveness, security in application, low energy consumption signal and transformations that do not affect or distort the control results.

The HR registration method of the proposed method combines all the benefits of optical methods of registration. By providing a high level of information, studies of one monitoring entity based on the analysis of heart rate records over a long time are possible. This, in turn, allows the individual components of the pulse curves to be monitored and digitized or quantified, and by analogy with the rhythmic approach to the dynamics of cardiac activity (Yankovenko, 2010), it is possible to determine the effect of nervous and humoral regulation on the contractile activity of the vascular system.

\section{Discussion}

The results of our study are consistent with a number of scientific studies (Schmidt \& Lee, 2013; Sartor et al., 2016; Ozemek et al., 2017) on the need to ensure the effectiveness of the control of functional systems in the process of physical training, which is the basis for regulating the rationality of pedagogical effects to ensure the effectiveness of physical education.

We support scientific approaches to ways to optimize controls in physical education using information systems (Koryahin, Blavt, Vanivska, \& Stadnyk, 2020; Vasconcelos,
Damorim, Santos, Lima, Santos, Lima, \& Damasceno, 2020). Our research is consistent with reports (Aadahl \& Jorgensen, 2003; Koryahin \& Blavt, 2018) that the automation of the process of obtaining and processing control information contributes to improving the speed of receipt, reliability and objectivity of information and its analysis in real time and significantly reducing the time lost on the implementation of control.

The results of the study complement the data on the control of the condition of the cardiovascular system in the process of physical education (Faulkner et al., 2013; Nichols et al., 2013).

Scientific ideas on real-time HR monitoring with the use of modern information systems have been further developed as an opportunity to significantly increase control efficiency.

Our study is consistent with a number of scientific findings that the transition to a fundamentally new system of quality assurance testing in physical education involves the use of innovative tools of control and diagnostics to ensure the reliability of results (Jrgensen et al., 2009; Oliver \& Stembridge, 2011).

\section{Conclusions}

At the present stage, the need for modernization of control procedures as an opportunity to improve the efficiency of physical education has been actualized. According to the results of the search activity, a device designed to monitor HR in real time is presented. The efficiency of the created device in the process of heart rate control was experimentally proved with the use of spectral analysis, which realizes the qualitative and quantitative characteristics of the condition of the cardiovascular system and the response of HR to physical activity in real time.

Using the developed device, a method of monitoring the functional state of the cardiovascular system, namely the control of HR during physical activity, is proposed. The use of information systems in HR control ensures the accuracy of the measurement information and the correspondence between the degree of scientific reliability and practical value of the obtained results. Equipping the process of HR control with modern means, including the field of nanotechnology, will undoubtedly contribute to ensuring a high level of control and, consequently, high efficiency of physical education.

\section{Conflict of interest}

The authors state no conflict of interest.

\section{References}

Anikieiev, D.M. (2015). Criteria of effectiveness of students' physical education system in higher educational establishments. Physical education of students, 19(5), 3-8. https://doi.org/10.15561/20755279.2015.0501

Schmidt, R.A., \& Lee, T.D. (2013). Motor learning and performance. From principles to application. 5 th ed. Champaign: Human Kinetics.

Zanevskyy, I., \& Zanevska, L. (2019). Validity of the Dickson index regarding primary school physical education. Hum Mov, 20(2), 44-49. https://doi.org/10.5114/hm.2019.81021

Dinesh, J., Sforzo, G., \& Swensen, T. (2007). Monitoring Exercise heart rate using manual palpation. Health and fitness Journal, 11(6), 14-18.

https://doi.org/10.1249/01.FIT.0000298450.02190.55 
Fedorov, V.A. (2018). Radio engineering methods in functional diagnostics of a human being. Publishing House MPEI. (in Russian)

Ozemek, C., Whaley, M.H., Finch, W. H., \& Kaminsky, L.A. (2017). Maximal heart rate declines linearly with age independent of cardiorespiratory fitness levels. European Journal of Sport Science, 17(5), 563-570. https://doi.org/10.1080/17461391.2016.1275042

Laurson, K.R., Brown, D.D., Dennis, K.K., \& Cullen, R.W. (2008). Heart Rates of High School Physical Education Students During Team Sports, Individual Sports, and Fitness Activities. Research Quarterly for Exercise and Sport, 79(1), 85-91. https://doi.org/10.1080/02701367.2008.10599463

Ivashchenko, O. (2020). Research Program: Modeling of Motor Abilities Development and Teaching of Schoolchildren. Teoriâ ta Metodika Fizičnogo Vihovannâ, 20(1), 32-41. https://doi.org/10.17309/tmfv.2020.1.05

Oliver, J.L., \& Stembridge, M. (2011). Use of a heart rate-toground contact time index to monitor and predict middledistance running. European Journal of Sport Science, 11(6), 431-436. https://doi.org/10.1080/17461391.2010.536582

Arena, R., Myers, J., \& Kaminsky, L.A. (2016). Revisiting agepredicted maximal heart rate: Can it be used as a valid measure of effort? American Heart Journal, 173, 49-56. https://doi.org/10.1016/j.ahj.2015.12.006

Jrgensen, T., Andersen, L.B., Froberg, K., Maeder, U.L., von Huth Smith, \& Aadahl, M. (2009). Position statement: Testing physical condition in a population - how good are the methods? European Journal of Sport Science, 9(5), 257267. https://doi.org/10.1080/17461390902862664

Thomas, J.R., Nelson, J.K., \& Silverman, S.J. (2015). Research methods in physical activity, 7th ed. Champaign: Human Kinetics.

Reiman, M.P., \& Manske, R.C. (2009). Functional testing in human performance. Champaign IL : Human Kinetics.

Fainsilberg, L.S. (2007). Diagnostic value of an electrocardiogram in phase space for screening for coronary heart disease. Ukrainian Journal of Cardiology, 6, 13-18. (in Russian)

Nichols, R., Davis, K.L., McCord, T., Schmidt, D. \& Slezak, A.M. (2013). The Use of Heart Rate Monitors in Physical Education. Strategies, 22(6), 19-23. https://doi.org/10.1080/08924562.2009.10590845

Alfrey, L., \& Gard, M. (2014). A crack where the light gets in: a study of Health and Physical Education teachers' perspectives on fitness testing as a context for learning about health. Asia-Pacific Journal of Health, Sport and Physical Education, 5(1), 3-18.

https://doi.org/10.1080/18377122.2014.867790

Osipov, A., Ratmanskaya, T., Nagovitsyn, R., Zhuikova, S., \& Iermakov, S. (2020). Increasing the level of cardiorespiratory and strength endurance of female students by means of mixed training (Kangoo-jumps fitness and resistance training). Physical Activity Review, 8(2), 38-47. https://doi.org/10.16926/par.2020.08.20

Koryahin, V., Blavt, O., \& Ponomaryov, S. (2019). Innovative Intestification of Testing of Strength Endurance in Physical Education of Students With Chronic Diseases. Teoriâ ta Metodika Fizičnogo Vihovannâ, 19(3), 116-122. https://doi.org/10.17309/tmfv.2019.3.02
Gasser, B.A., \& Hoppeler, H.H. (2015). Performance diagnostic in cross-country skiing. Hum Mov, 16(2), 83-87. https://doi.org/10.1515/humo-2015-0030

Vasconcelos, G.C., Damorim, I.R., Santos, T.M., Lima, T., Santos, R., Lima, A., \& Damasceno, V. (2020). Validation of a smartphone application for the measurement of heart rate during exercise. Hum Mov, 21(2), 25-31. https://doi.org/10.5114/hm.2020.89911

Cooper, J.A., Watras, A.C., O’Brien, M.J., Luke, A., Dobratz, J.R., Earthman, C.P., \& Schoeller, D.A. (2009). Assessing validity and reliability of resting metabolic rate in six gas analysis systems. Journal of the American Dietetic Association, 109(1), 128-132. https://doi.org/10.1016/j.jada.2008.10.004

Faulkner, J., Greey, G. \& Hunsicker, P. (2013). Heart Rate during Physical Education Periods. Research Quarterly. American Association for Health, Physical Education and Recreation, 34, 95-98. https://doi.org/10.1080/10671188.1963.10613224

Yankovenko, O. D. (2010). Eksperymentalne doslidzhennia funktsionalnoho stanu liudyny na osnovi amplitudnoho spektralnoho analizu pulsovoi khvyli. Visnyk Natsionalnoho tekhnichnoho universytetu Ukrainy Kyivskyi politekhnichnyi instytut. Seriia: Radiotekhnika. Radioaparatobuduvannia, (40), 35-41. (in Ukrainian)

Warburton, D.E.R., Nicol, C.W., \& Bredin, S.S.D. (2006). Health benefits of physical activity: The evidence. CMAJ, 174(6), 801-809.

Hotra, Z., Mahlovanyy, A., Mykytyuk, Z., Ivakh, M., \& Politanskyi, R. (2019). Schematic Realization of Flexible Algorithm in Treatment Diagnostic Devices. IEEE XVth International Conference on the Perspective Technologies and Methods in MEMS Design. https://doi.org/10.1109/MEMSTECH.2019.8817378

American College of Sports Medicine. (2013). ACSM's Guidelines for Exercise Testing and Prescription. 9th ed. Philadelphia, PA: Lippincott Williams \& Wilkins.

Sartor, F., Bonato, M., Papini, G., Bosio, A., Mohammed, R.A., \& Bonomi, A.G., et al. (2016). A 45-second self-test for cardiorespiratory fitness: heart rate-based estimation in healthy individuals. PLoS One. Hum Mov, 11(12), e0168154. https://doi.org/10.1371/journal.pone.0168154

Malaric, R. (2011). Instrumentation and Measurement in Electrical Engineering. BrownWalker Press. Boca Raton, Florida. USA.

Koryahin, V., Blavt, O., Vanivska, O., \& Stadnyk, V. (2020). Potential of new technologies in providing efficiency of pedagogical control in physical education. Teoriâ ta Metodika Fizičnogo Vihovannâ, 20(1), 25-31. https://doi.org/10.17309/tmfv.2020.1.04

Aadahl, M., \& Jorgensen, T. (2003). Validation of a new self-report instrument for measuring physical activity. Medicine and Science in Sports and Exercise, 35, 1196-1202. http://doi.org/10.1249/01.mss.0000074446.02192.14

Koryahin, V., \& Blavt, O. (2018). The Use of Information and Communication Technology for Determining the Level Mobility in Joint in Physical Education of Students. Teoriâ ta Metodika Fizičnogo Vihovannâ,18(3), 107-113. https://doi.org/10.17309/tmfv.2018.3.01 


\title{
ІНТЕГРАЦІЯ ІНФОРМАЦІЙНИХ СИСТЕМ У КОНТРОЛІ ЧАСТОТИ СЕРЦЕВИХ СКОРОЧЕНЬ В ПРОЦЕСІ ФІЗИЧНОГО ВИХОВАННЯ
}

\author{
Віктор Корягін ${ }^{1 \mathrm{ABCD}}$, Зіновій Микитюк ${ }^{1 \mathrm{ABCD}}$, Ярина Турчин ${ }^{1 \mathrm{ABCD}}$, \\ Оксана Блавт ${ }^{1 \mathrm{ABCD}}$, Володимир Пристинський ${ }^{2 \mathrm{ABCD}}$, Володимир Стадник ${ }^{1 \mathrm{ABCD}}$ \\ ${ }^{1}$ Національний університет «Львівський політехніка» \\ ²Державний вищий навчальний заклад «Донбаський державний педагогічний університет» \\ Авторський вклад: А - дизайн дослідження; В - збір даних; C - статаналіз; D - підготовка рукопису; Е - збір коштів \\ Реферат. Стаття: 8 с., 3 рис., 31 джерело.
}

Мета дослідження - обгрунтування та реалізація засобу контролю частоти серцевих скорочень, розробленого на основі інформаційних систем для здійснення оперативної реєстрації серцевого ритму при фізичному навантаженні.

Матеріал та методи. Дослідження виконано на теоретичному та емпіричному рівнях. Основою дослідження $є$ використання комплексу теоретичних методів: наукового аналізу, синтезу, порівняння, систематизації, індукції та дедукції, узагальнення. Серед методів емпіричного дослідження використовувалися: опис, емпіричне порівняння, технічне моделювання, сфігмографічний метод реєстрації пульсограми.

Результати. За результатами пошукової діяльності представлено пристрій, призначений для контролю частоти серцевих скорочень у режимі реального часу. Основою пристрою є створений оптичний блок на основі оптичного датчика. Використання оптичного блоку забезпечує реєстрацію динамічного вимірювання частоти серцевих скорочень, який побудовано так, щоб отримувати дані спектру крові та зміни у ньому. Для реєстрації серцевого ритму використано багатопараметричний аналіз спектральних ха- рактеристик крові, які змінюються під впливом фізичних навантажень. На основі такого аналізу отримують якісні та кількісні характеристики стану серцево-судинної системи та інформацію про реакцію серцевого ритму на фізичні навантаження в режимі реального часу. До позитивних характеристик, які забезпечують якість контролю частоти серцевих скорочень в режимі реального часу з використанням розробленого пристрою, крім високих технічних параметрів (високий рівень чутливості, широкий динамічний діапазон, гармонізована частотна характеристика, лінійність перетворення), відзначено й неінвазивність, безпечність у застосуванні, низьку енергетику отримання інформаційного сигналу та перетворення, які не впливають та не спотворюють результати контролю.

Висновки. Застосування інформаційних систем у контролі частоти серцевих скорочень забезпечує точність подання вимірювальної інформації та відповідність між ступенем наукової достовірності й практичної цінності отриманих результатів.

Ключові слова: фізичне виховання, частота серцевих скорочень, пульсограма, пристрій, датчик, контроль.

\section{Information about the authors:}

Koryahin V.: koryahinv@meta.ua; https://orcid.org/0000-0003-1472-4846; Department of Physical Education, Lviv Polytechnic National University, Bandera St, 12, Lviv, 79013, Ukraine.

Mykytyuk Z.: zm.mykytiuk@gmail.com; https://orcid.org/0000-0002-1944-2015; Lviv Polytechnic National University, Bandera St, 12, Lviv, 79013, Ukraine

Turchyn Y.: turchynj@ukr.net; http://orcid.org/0000-0002-9114-1911; Department of Physical Education, Lviv Polytechnic National University, Bandera St, 12, Lviv, 79013, Ukraine.

Blavt O.: oksanablavt@ukr.net; https://orcid.org/0000-0001-5526-9339; Department of Physical Education, Lviv Polytechnic National University, Bandera St, 12, Lviv, 79013, Ukraine.

Prystynskyi V.: v.prystynskyi@hotmail.com; https://orcid.org/0000-0003-1681-3543; Department of Theoretical, Methodological Foundations of Physical Education and Rehabilitation, State Higher Educational Institution "Donbass State Pedagogical University", Batiuka St, 19, Sloviansk, 84116, Ukraine.

Stadnyk V.: vova121212131313@ukr.net; https://orcid.org/0000-0002-2864-4794; Lviv Polytechnic National University, Bandera St, 12, Lviv, 79013, Ukraine.

Cite this article as: Koryahin, V., Mykytyuk, Z., Turchyn, Y., Blavt, O., Prystynskyi, V., \& Stadnyk, V. (2021). Integration of Information Systems in the Control of Heart Rate in the Process of Physical Education. Teoriâ ta Metodika Fizičnogo Vihovannâ, 21(1), 5-11. https://doi.org/10.17309/tmfv.2021.1.01

Received: 23.11.2020. Accepted: 20.03.2021. Published: 25.03.2021

This work is licensed under a Creative Commons Attribution 4.0 International License

(http://creativecommons.org/licenses/by/4.0). 